University of Nebraska - Lincoln

DigitalCommons@University of Nebraska - Lincoln

2010

Descriptions of life-stages of Blastobasis repartella (Lepidoptera:

Gelechioidea: Coleophoridae: Blastobasinae) and observations on its biology in switchgrass

D. Adamski

Smithsonian Institution, adamskid@si.edu

P. J. Johnson

South Dakota State University, paul.johnson@sdstate.edu

A. A. Boe

South Dakota State University, arvid.boe@sdstate.edu

Jeffrey Bradshaw

University of Nebraska-Lincoln, jbradshaw2@unl.edu

Alan Pultyniewicz

Follow this and additional works at: https://digitalcommons.unl.edu/panhandleresext

Part of the Agriculture Commons

Adamski, D.; Johnson, P. J.; Boe, A. A.; Bradshaw, Jeffrey; and Pultyniewicz, Alan, "Descriptions of lifestages of Blastobasis repartella (Lepidoptera: Gelechioidea: Coleophoridae: Blastobasinae) and observations on its biology in switchgrass" (2010). Panhandle Research and Extension Center. 46. https://digitalcommons.unl.edu/panhandleresext/46

This Article is brought to you for free and open access by the Agricultural Research Division of IANR at DigitalCommons@University of Nebraska - Lincoln. It has been accepted for inclusion in Panhandle Research and Extension Center by an authorized administrator of DigitalCommons@University of Nebraska - Lincoln. 


\title{
Descriptions of life-stages of Blastobasis repartella (Lepidoptera: Gelechioidea: Coleophoridae: Blastobasinae) and observations on its biology in switchgrass
}

\author{
D. ADAMSKI ${ }^{1}$, P. J. JOHNSON ${ }^{2}$, A.A. BOE ${ }^{3}$, J.D. BRADSHAW ${ }^{4}$ \& ALAN PULTYNIEWICZ ${ }^{5}$ \\ ${ }^{\prime}$ Department of Entomology, National Museum of Natural History, P. O. Box 37012, NHB - E519, Smithsonian Institution, Washington, \\ D.C. 20013-7012, USA. E-mail: adamskid@si.edu \\ ${ }^{2}$ Insect Research Collection, Box 2207A, South Dakota State University, Brookings, SD 57007, USA. \\ E-mail: paul.johnson@sdstate.edu \\ ${ }^{3}$ Plant Science Department, Box 2140C, South Dakota State University, Brookings, SD 57007, USA. E-mail: arvid.boe@sdstate.edu \\ ${ }^{4}$ Panhandle Research and Extension Center, University of Nebraska-Lincoln, 4502 Ave I Scottsbluff, NE 69361, USA. \\ E-mail: jbradshaw2@unl.edu
}

${ }^{5} 6148$ Agail Place, Columbia, MD 21045, USA

\begin{abstract}
Blastobasis repartella (Dietz) is a borer in the proaxis and basal nodes and internodes of above ground stems of Panicum virgatum L. (Poaceae). The adult and immature stages are described herein, including diagnoses of the adult and larva, as this insect may be easily confused with a closely related grass-feeding congener, Blastobasis graminea Adamski, which is also known to occur in the United States. The biology of B. repartella is described. Figures of the adult, illustrations of the male and female genitalia, wing venation, the chaetotaxy of the larva (supplemented with scanning electron micrographs), and pupa are provided. Bassus difficilis (Hymenoptera: Braconidae) is reported as a larval/pupal parasitoid of $B$. repartella. A new host record for Aethes spartinana (Barnes \& McDunnough) (Lepidoptera: Tortricidae) is also reported.
\end{abstract}

Key words: biofuel, biomass, Blastobasinae, chaetotaxy, Coleophoridae, energy, Gramineae, life stages, Panicum, Poaceae, stem-borer, switchgrass

\section{Introduction}

Switchgrass, Panicum virgatum L. (Poaceae), is one of the abundant graminaceous species that contribute to the prairies of the Great Plains. This species and others function to control soil erosion within the grassland ecosystem, which historically has had an inverse relationship between conservation of this ecosystem and human settlement (Samson and Knopf 1994). Within recent decades, components of this grassland system, e.g., switchgrass, have been selected and developed to serve as a component species in pasture and in the Conservation Reserve Program (Schmer et al. 2008). Very recently, renewed interests in research has aimed to exploit cellulosic energy sources originating from the entire prairie (Tilman et al. 2006) to component species such as switchgrass (Schmer et al. 2008; Vogel \& Mitchell 2008; Jakob, et al. 2009). Land-change plans in agriculture are underway to accommodate this growing cellulosic market (USDOE, 2006). This may mean that biological components of the system that were once in decline may change direction. These changes will enhance our need acquire knowledge of insect species such as Blastobasis repartella, that feed on these grasses.

Blastobasis repartella was described by Dietz (1910) from two male specimens collected from Denver, Colorado. The lectotype and paralectotype are deposited in the National Museum of Natural History, Smithsonian Institution, Washington, DC, USA (Adamski \& Hodges 1996). Little had been known of the identity of this moth or its biology until collaborative efforts by the authors was initiated. 
The biologies of Blastobasis species vary greatly. Some species appear strictly phytophagous. For example, $B$. graminea Adamski and $B$. repartella, are stem-borers; the former feeding on various species of grasses, whereas the latter species appears to be restricted to switchgrass. Other species of Blastobasis are recorded as being phytophagous and/or detritivorous, e.g., as B. lacticilella Rebel, which feeds on apples on the tree and in storage, dead insects, seed pods of wild lupine, tansy, spiny oak-galls, and dried fruit skins (Chipperfield 1978; O’Keeffe 1991; Dickson 2002). In addition, B. adjustella Walsingham and B. lacticolella are associated with galls as secondary opportunists.

Blastobasis is defined by having a first flagellomere of the male antenna that is subconical, with the inner surface of dilated and bearing palmate scales, a forewing with the cubitus appearing 4-branched producing three cells of near equal shape and size, ventral medial margin of gnathos unidentate or bidentate, corpus bursae usually with a posterolateral lobe, and and inception of ductus seminalis and ductus bursae originating from a short membranous duct from ostium (Adamski \& Brown 1989). Blastobasis is the largest genus within the Blastobasinae (Coleophoridae) with approximately 120 described species worldwide. This number undoubtedly will increase as nearly 30 species will be described from Africa (Adamski et al. 2010) and Costa Rica (Adamski in prep), and many more undescribed species remain in various institutional collections awaiting study.

The purpose of this study of $B$. repartella is to 1 ) redescribe the adult and to describe the immature stages, 2) describe its biology and document its distribution, 3) and provide a diagnosis for this species and $B$. graminea, which are both similar in bionomics and may be sympatric in parts of their distribution.

\section{Material and methods}

Switchgrass tillers ranging from 15-38 cm were collected from experimental plots in Brookings County,

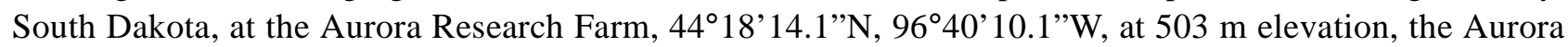
Prairie, $44^{\circ} 15^{\prime} 45.1^{\prime \prime} \mathrm{N}, 96^{\circ} 42^{\prime} 17.9^{\prime \prime} \mathrm{W}$, at $488 \mathrm{~m}$, the Soil and Water Research Farm, $44^{\circ} 20^{\prime} 59.9^{\prime} \mathrm{N}$, $96^{\circ} 48^{\prime} 00^{\prime} \mathrm{W}$, at $506 \mathrm{~m}$ elevation, and in Savoy, Champaign County, Illinois at the Soyface Farm, $40^{\circ} 2^{\prime} 31.64^{\prime \prime} \mathrm{N}, 88^{\circ} 13^{\prime} 30.90^{\prime \prime} \mathrm{W}$, at $224 \mathrm{~m}$ elevation. Most field collected larvae were extracted from the rhizomes and stems with forceps or a camel's hair brush and placed into diet cups partially filled with a standard sugarcane borer diet from Southland Products, Lake Village, AR, while some adults were reared from larvae collected from stems that were brought to the laboratory, cut to lengths of 10-12 cm, and placed into plastic boxes with moistened soil. Representative field collected larvae and pupae were boiled in $\mathrm{H}_{2} \mathrm{O}$ and preserved in $70 \% \mathrm{EtOH}$ for later examination. Newly emerged adults were frozen and later spread and double-mounted.

Additional samples of adult specimens were field collected using emergence cages. Simple square cages, approximately $61 \mathrm{~cm}$ on each side, were constructed of $5 \times 5 \mathrm{~cm}$ untreated lumber (Pinus sp.) and standard plasticized window screening. One side, used as the bottom of the cage was unscreened. These cages were placed, open side down, over one to several infested switchgrass plants and monitored daily at or shortly after sunrise. Males of $B$. repartella, presumably attracted by calling females (within the cages) during the night, were found entrapped in morning dew on the outside of the cages. These male specimens were collected, pinned, and labeled.

For SEM study, larvae and pupae were cleaned in a full-strength solution of Formula $409^{\mathrm{TM}}$ detergent, and subsequently dehydrated in increasing concentrations of $\mathrm{EtOH}(10,25,50,70,95 \%)$, ending with absolute EtOH. After dehydration, specimens were critical point dried using a Tousimis critical point dryer, mounted on SEM stubs using carbon paste, and coated with gold-palladium (40/60\%), using a Cressington sputter coater. Forewings were disarticulated from the mesothorax of pinned specimens and mounted on stubs using carbon adhesive tabs. The fine structure of the larva, pupa, and the male sex scales on the undersurface of the forewing was studied with an Amray 1810 scanning electron microscope at an accelerating voltage of $10 \mathrm{kV}$.

Morphological examinations and measurements of the adults, larvae, and pupae were made using a Leitz RS dissecting microscope with a calibrated micrometer. Genitalia were dissected as described by Clarke 
(1941), except mercurochrome and chlorazol black were used as stains. The male and female genitalia are described as how they are oriented naturally on the body and not how they are figured. The Methuen Handbook of Colour (Kornerup \& Wanscher 1978) was used as a color standard. Voucher specimens of adult and immature stages of $B$. repartella and its parasitoids obtained from this study are deposited in The United States National Museum of Natural History, Smithsonian Institution, Washington, D.C. (USNM), the Illinois Natural History Survey, Champaign, Illinois (INHS), the Severin-McDaniel Insect Collection (SMIRC), Brookings, South Dakota, and the Steven Passoa Collection, Columbus, Ohio. The larval description is based upon the last instar. Larval nomenclature follows Stehr (1987); pupal nomenclature follows Mosher (1916).

\section{Results}

\section{Blastobasis repartella (Dietz 1910)}

Adult diagnosis. Blastobasis repartella is similar to B. graminea in wing pattern, but differs from the latter species by having males with a unidentate medial process on the ventroposterior margin of the gnathos, sparse tergal setae, an absence of the dorsal strut of tegumen, an anellus of the phallus that is broadly round apically, and females with a corpus bursae lacking a small lobe on the posterior end, and by having a smaller signum.

Adult redescription. (Figs. 1-6): Head: Pale grayish orange except, outer surface of labial palpus as above or grayish orange intermixed with few brown scales.

Thorax: Scales of tegula and mesonotum pale grayish orange or pale grayish orange intermixed with a few brown scales. Legs pale grayish orange. Forewing (Fig. 1), length ô, 5.5-7.2 mm (n = 10);, , 7.0-9.1 mm (n =15). Grayish orange to pale grayish orange intermixed with few brown scales, veins overlaid with few brown scales, appearing faintly streaked; discal cell with 2 or 3 dark-brown spots, one present or absent near midcell and two near distal end of cell; undersurface brown. Venation (Fig. 2), cubitus appearing 4-branched, $\mathrm{M}_{3}-\mathrm{CuA}_{1}$ connate. Hindwing translucent, pale gray. Venation (Fig. 3); cubitus 4-branched, closer to margin than to chorda, each vein appearing similar in length; frenulum with one acanthus in male, three acanthae in female.

Abdomen (Figs. 4-6): Anterior 3/4 of terga 1-7 of male and 1-6 of female with 5-6 irregular, transverse rows of spiniform setae, posterior pale yellowish brown; undersurface pale yellowish brown. Male Genitalia (Figs. 4-5): Uncus sparsely setose, wide basally, gradually narrowing apically to a slightly indented apex; ventroposterior margin of gnathos unidentate medially; dorsal strut of tegumen absent; tergal setae sparse; diaphragma microtrichiate throughout, forming a pleat above phallus, extending laterally from middle to and above ventrolateral margins of proximal flange, forming an elliptical-shaped, densely microtrichiate process; microtrichiate process intermixed with spinules on ventrolateral margin; juxta bandlike; vinculum semicircular; phallus with internal support, acutely curved near apical 1/3, slightly curved near base; anellus broadened apically, bearing several conical setae. Female Genitalia (Fig. 6): Ovipositor telescopic, with four membranous subdivisions posterior to $8^{\text {th }}$ segment; ostial opening within slightly microtrichiate membrane posterior to seventh segment; ductus bursae narrow, gradually widening anteriorly, about as long as ovipositor, anterior $1 / 3$ lined with two rows of imbricate platelike processes; inception for ductus seminalis near posterior end of seventh segment; corpus bursae elliptical, with a small spinelike signum near midlength.

Larval diagnosis.- Blastobasis repartella is similar to B. graminea in feeding habits, size, and chaetotaxy but differs from the latter species by having darker pinacula, an elliptical diffuse spot on the prothoracic shield within area between SD1, XD2, SD2, and D2, and SD1 hairlike on A8.

Larva: description. (Figs. 7-21): Length $8.3-12.0 \mathrm{~mm}(\mathrm{n}=59$ preserved larvae). Body pale gray to white, smooth; head capsule, prothoracic shield, thoracic legs, and anal shield yellowish brown; pinacula small, brown; circular spiracles on T1 and A10 with equal diameters, slightly larger than spiracles on A1-A8. 


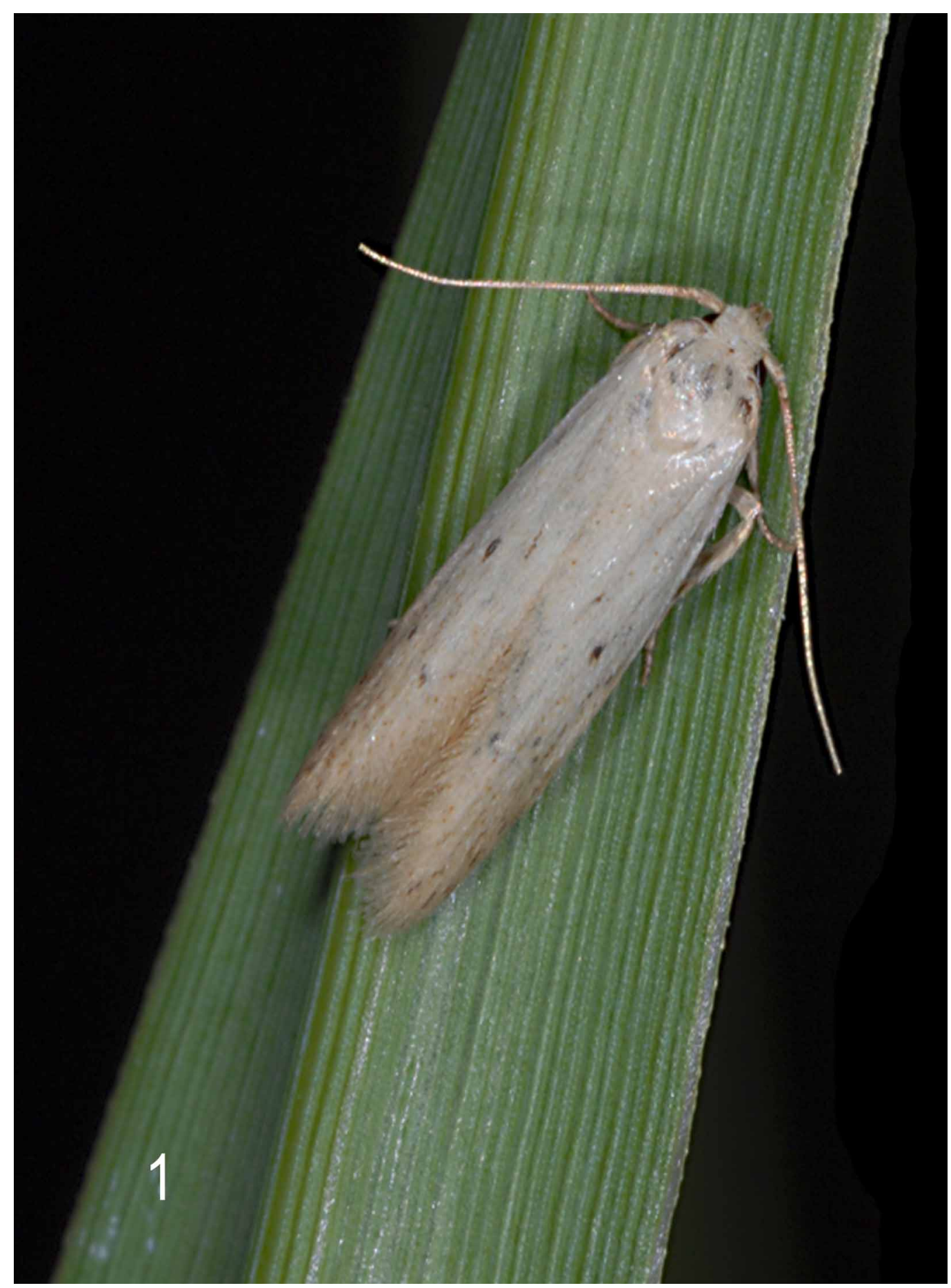

FIGURE 1. Live adult of Blastobasis repartella.

Head (Figs. 7 - 12, 20): Hypognathous; epicranial suture extending to epicranial notch, beyond apex of frons, dividing head into two hemispheres; adfrontal sclerites delimiting frons; frons widened basally, gradually narrowing to apex (Fig. 7); AF2s slightly above or at same level of apex of frons; AF2 and AF1 about same lengths, slightly shorter than F1; distance between AF1 and AF2 about 3x distance between AF1 and $\mathrm{F} 1$; distance between $\mathrm{F} 1$ and $\mathrm{AF} 1$ about $3 \mathrm{x}$ distance between $\mathrm{F} 1$ and $\mathrm{C} 2$; $\mathrm{C} 1$ slightly longer than $\mathrm{C} 2$; $\mathrm{P} 1$ and A1 longest cranial setae; $\mathrm{P} 1$ about $4 \mathrm{x}$ length of $\mathrm{P} 2$, both below AF2, P2 slightly dorsal to P1; P2 in straight diagonal line with MD1 and MD2 (Fig. 8); L1 about length of and posteroventral to A3; A3 above stemmata 1-2; A1 about 1/3 longer than A2, in near straight line with $\mathrm{C} 2$ setae, both perpendicular to median longitudinal axis; of six stemmata, five stemmata (1-4 and 6) in a semicircle, stemmata 3-4 approximate; 

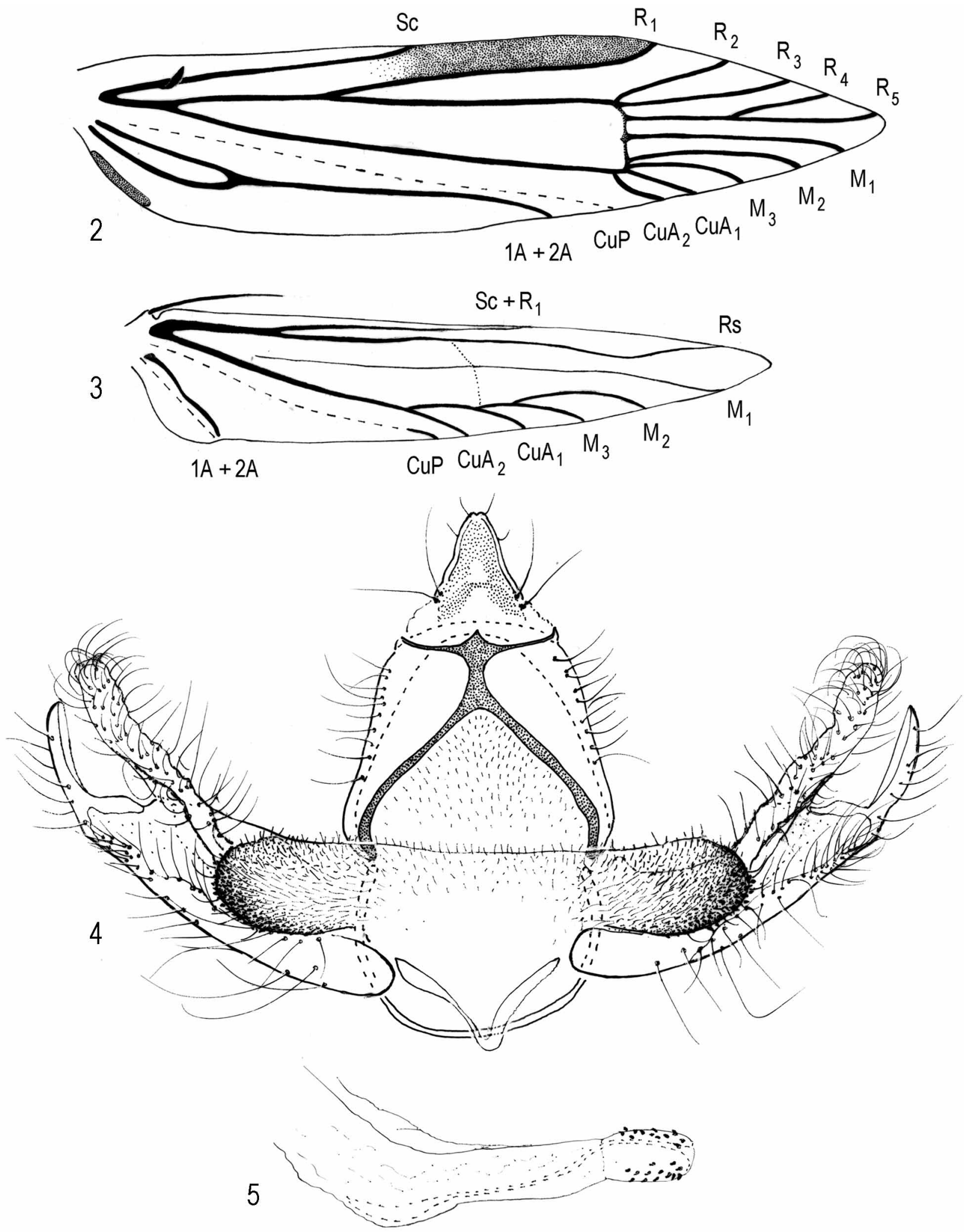

FIGURES 2-5. Wing venation and male genitalia of Blastobasis repartella. 2-3, venation of forewing and hindwing; 4 , genital capsule; 5 , phallus. 

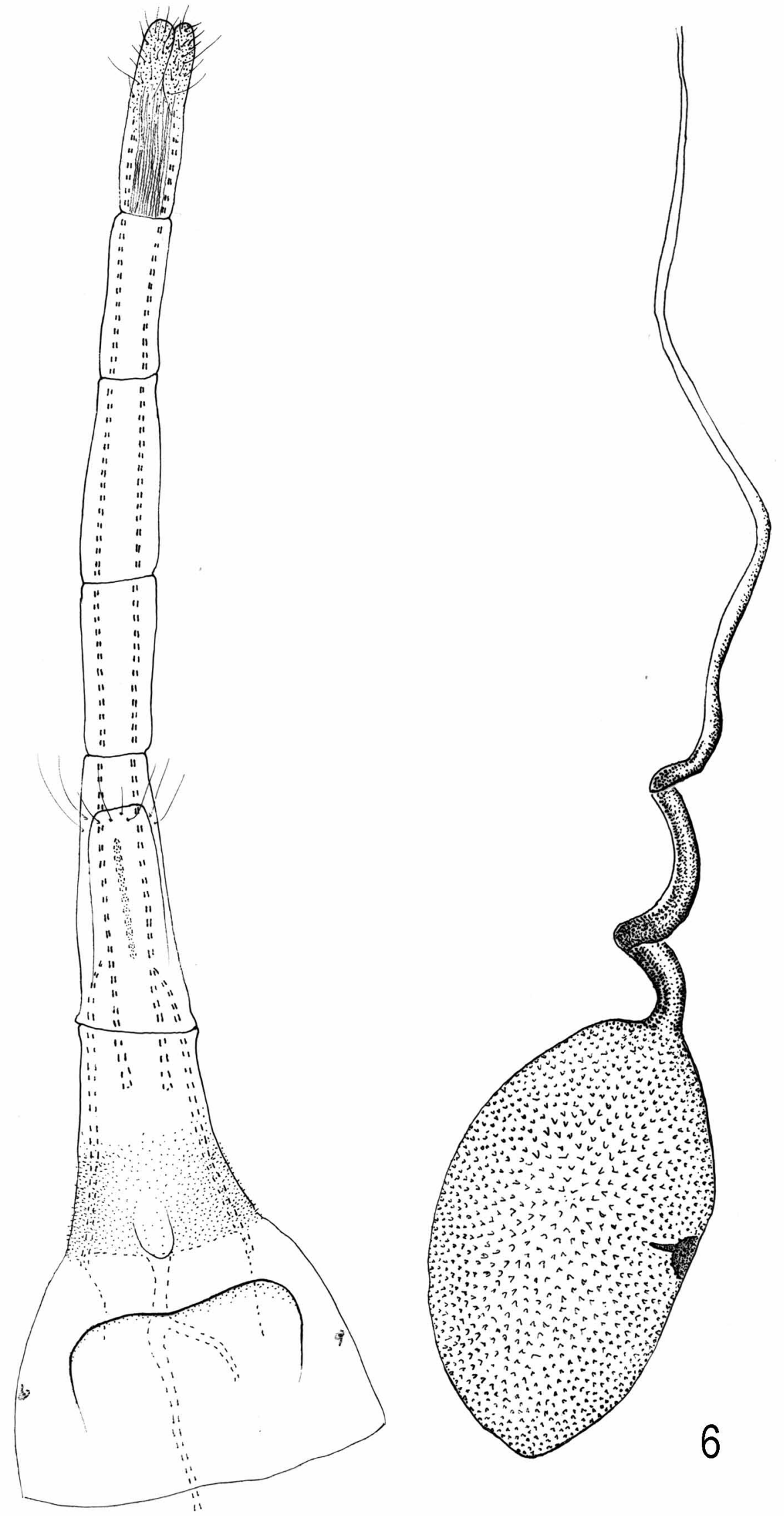

FIGURE 6. Female genitalia. 

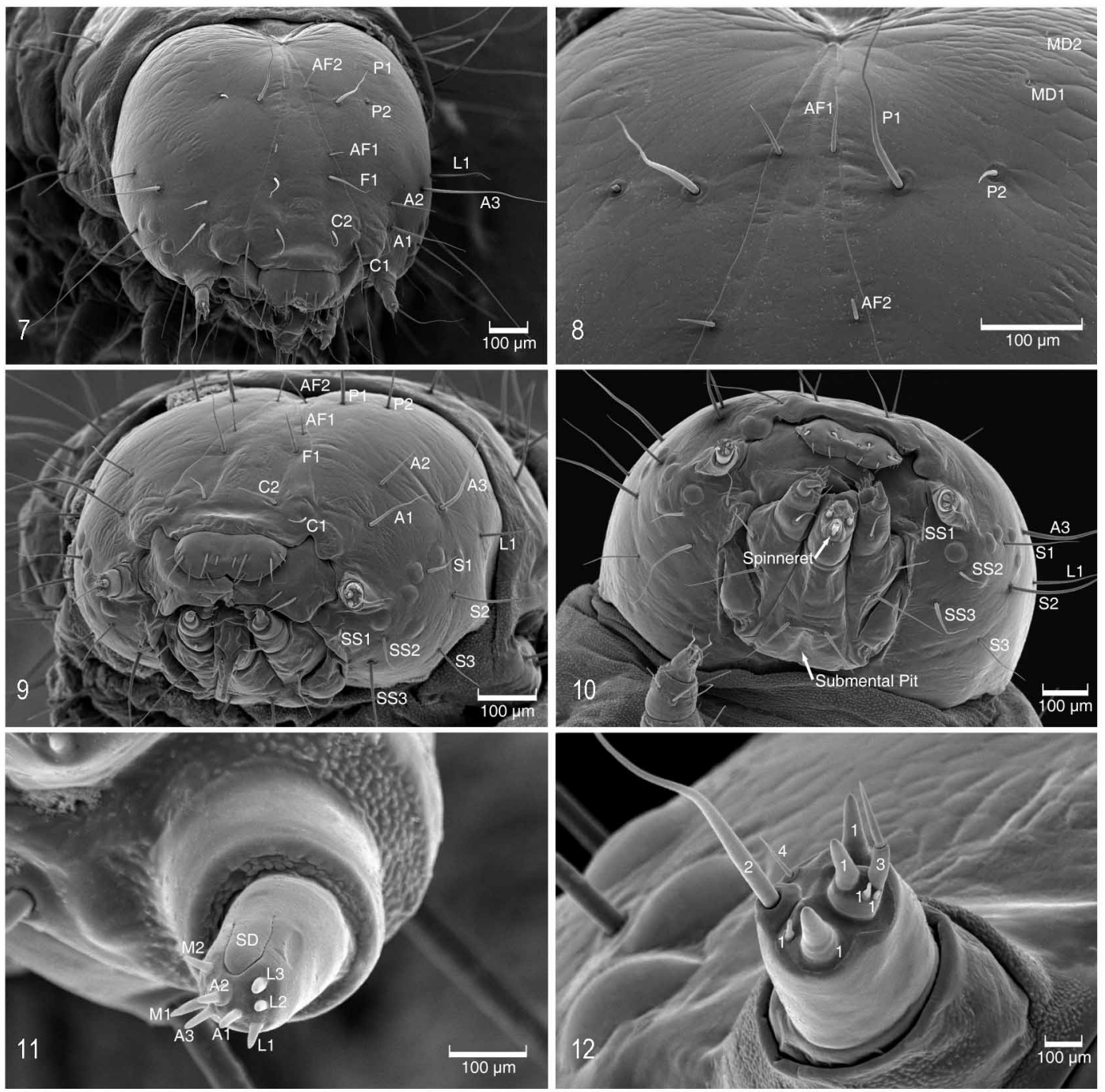

FIGURES 7-12. Scanning electron micrographs of larva of Blastobasis repartella. 7, head, frontal view; scale $=100$ $\mu \mathrm{m} ; 8$, head, anterodorsal view; scale $=100 \mu \mathrm{m} ; 9$, head, frontolateral view; scale $=100 \mu \mathrm{m} ; 10$, head, ventral view; scale $=100 \mu \mathrm{m} ; 11$, apical sensilla of left maxillary palpus; A2 = sensillum styloconicum; A1, A3, M1, M2, L1, L2, L3 = sensilla basiconica; $\mathrm{SD}=$ sensillum digitiform; scale $=100 \mu \mathrm{m} ; 12$, apical sensilla of left antenna; $1=$ sensilla basiconica, $2=$ sensilla chaetica, $3=$ sensillum styloconicum, $4=$ sensullum trichodeum; scale $=100 \mu \mathrm{m}$.

stemma 5 beneath antenna (Fig. 9); S2 beneath stemma 1, about 3x longer than S1 and S3 (Fig. 10); S3 on lower aspect of gena, and posterolateral of SS3; S2 slightly beneath and between stemmata 2-3; SS1 beneath antenna; SS2 between stemmata 5-6; SS3 posterior to and closer to midline than SS2; labrum with six pairs of setae, two subequal pairs medially; two subequal pairs along proximolateral margin, and two pairs of equal lengths along margin lateral to notch; mandible with two large dentitions flanked by two smaller dentitions, and bearing two subequal setae dorsally (Fig. 20); sensilla of maxillary palpus as in Fig. 11 sensilla of antenna as in Fig. 12; posterior part of labium with two divergent setae slightly anterior to submental pit; spinneret cylindrical and elongate.

Thorax: T1(Figs. 13, 17-18): Prothoracic shield dark brown on posterior $1 / 3$ and along lateral margins, paler to anterior margin, a pale diffuse, elliptical spot on each side of shield within area between SD1, XD2, SD2, and D2 (Figs. 17-18); shield with six pairs of setae; SD1, XD2, and XD1 along anterior margin in a straight line; XD2 and XD1 about equal in lengths, about shorter than SD1; SD2 shortest seta, slightly closer to SD1 than to XD2; D2 longest seta, slightly posterior to SD2, posterior and between XD2 and XD1, forming a large triangle; D1 slightly longer than SD2, posterior to D2 and closer to median longitudinal axis than XD1; L-group trisetose, in a straight line, with L2 about length of L1 (both pointing anteriorly) and L3 (pointing 
posteriorly) about 1/3 length of L1; MV2 anterior to SV-group; SV1 about 2x length of SV2, both setae on same or separate pinacula; coxae and V1s approximate, about closer than on T2-T3 (not shown); pretarsus with two setae above claw and two setae beneath claw (Fig. 13). T2-T3 (Figs. 17-18): D2 about 3x length of D1, each on same pinaculum; MD1 slightly above D-group pinaculum; MSD1 and MSD2 on same pinaculum, slightly below D-Group pinaculum; SD2 about 3x length of SD1, both on same pinaculum ventral and slightly anterior to D-group pinaculum; L1 about 3x length of L2, both setae on same pinaculum anteroventral to SD-group pinaculum; L3 equal in length to L2, dorsoposterior to L1-L2 pinaculum, and anterior to or in straight line with SV1; SV1 about same length as L1; MV1 dorsoanterior to SV1.
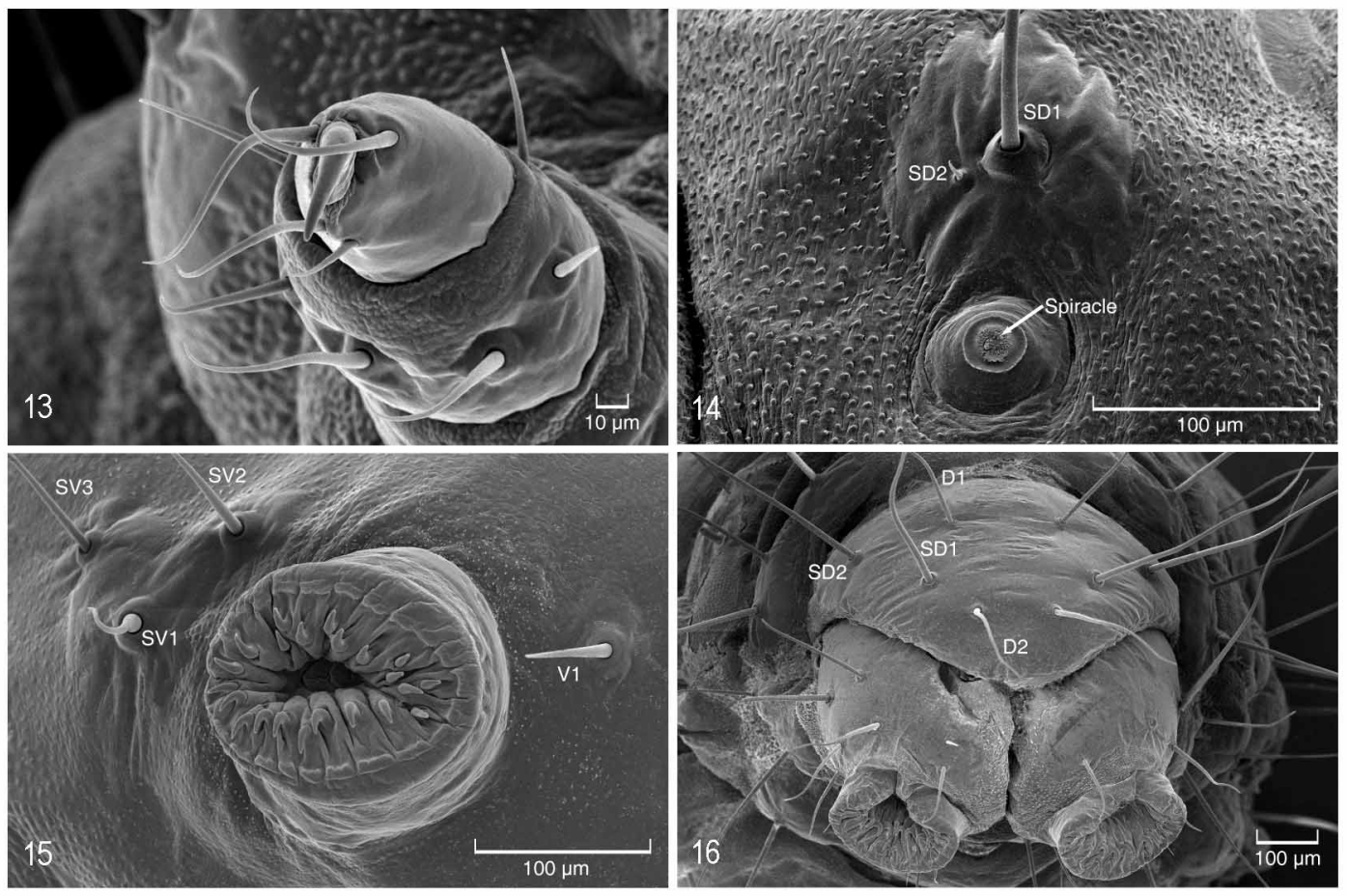

FIGURES 13-16. Scanning electron micrographs of larva of Blastobasis repartella. 13, claw of right leg on T1; 14, spiracle and associated setae on A1, lateral view; scale $=100 \mu \mathrm{m} ; 15$, right proleg on A3, ventral view; scale $=100 \mu \mathrm{m}$; 16, anal plate on A10, posterior view; scale $=100 \mu \mathrm{m}$.

Abdomen: A1-A2 (Figs. 14-16, 19, 21): D2 posteroventral to and about 2x length of D1; MD1 anteroventral to D2; SD-setae on same pinaculum above spiracle; SD1 about equal in length to D2, SD2 minute (Figs. 19, 21, 14 (enlarged); L2 about length of SD1, about 2x longer than L1, both setae on same pinaculum beneath spiracle; L3 about same length as L2, in near vertical line with D2; MV1 dorsoanterior to L3; SV-group trisetose, transverse to vertical line; V1-group as in T2-T3, except on larger pinacula (not shown); A3-A6 (Figs. 15, 21): as above except, SV-group in a triangular pattern, each seta on a separate pinaculum; planta of prolegs bearing uniserial crochets, uniordinal in a circle (as in Fig. 15) or biordinal mesally, gradually shortening laterally (Fig. 15); A7: as above except, SV-group bisetose, with SV1 about 2x length of SV2; A8 as above except, SD1 hairlike, SD2 absent, SV-group unisetose, and V1s slightly closer (not shown); A9 with D2 and D1 approximate, with the latter more ventral; D2, SD1, L2, and L1 in a straight line, anterior to L3 and SV1; MV1 not observed; V1s slightly farther apart than V1s on other segments; A10 with shield bearing four pairs of setae (Figs. 16, 21); SD1 and SD2 about equal in lengths, slightly longer than D1 and D2; D2 slightly decumbent; D1s in straight line with SD2s; prolegs with crochets uniordinal (as in Fig. 16) or biordinal.

Pupa. (Figs. 22-23): Length 5.5-6.2 mm $(\mathrm{n}=6)$ : yellowish brown; antennal sclerite widely curved laterally from vertex, extending caudally, converging beyond junction of maxillary sclerites, extending in parallel slightly before wing margins, apically diverging, exposing apices of metathoracic legs; prothoracic leg sclerites extending before apices of maxillae; mesothoracic leg sclerites surrounding caudolateral margins 
of prothoracic leg sclerites; prothoracic femoral sclerites about length of maxillae; abdominal spiracles protuberant; scars of prolegs on A5-A6.

Types examined. Lectotype $\sigma^{x}$, Valentinia repartella Dietz, 1910: Denver Colorado, USNM Genitalia slide 80987; Holotype + , Blastobasis graminea Adamski, 1999: Palmira, Cauca Valley, Colombia. Primary types and larvae of $B$. graminea from same location of holotype were examined at the United States National Museum of Natural History, Washington, DC.
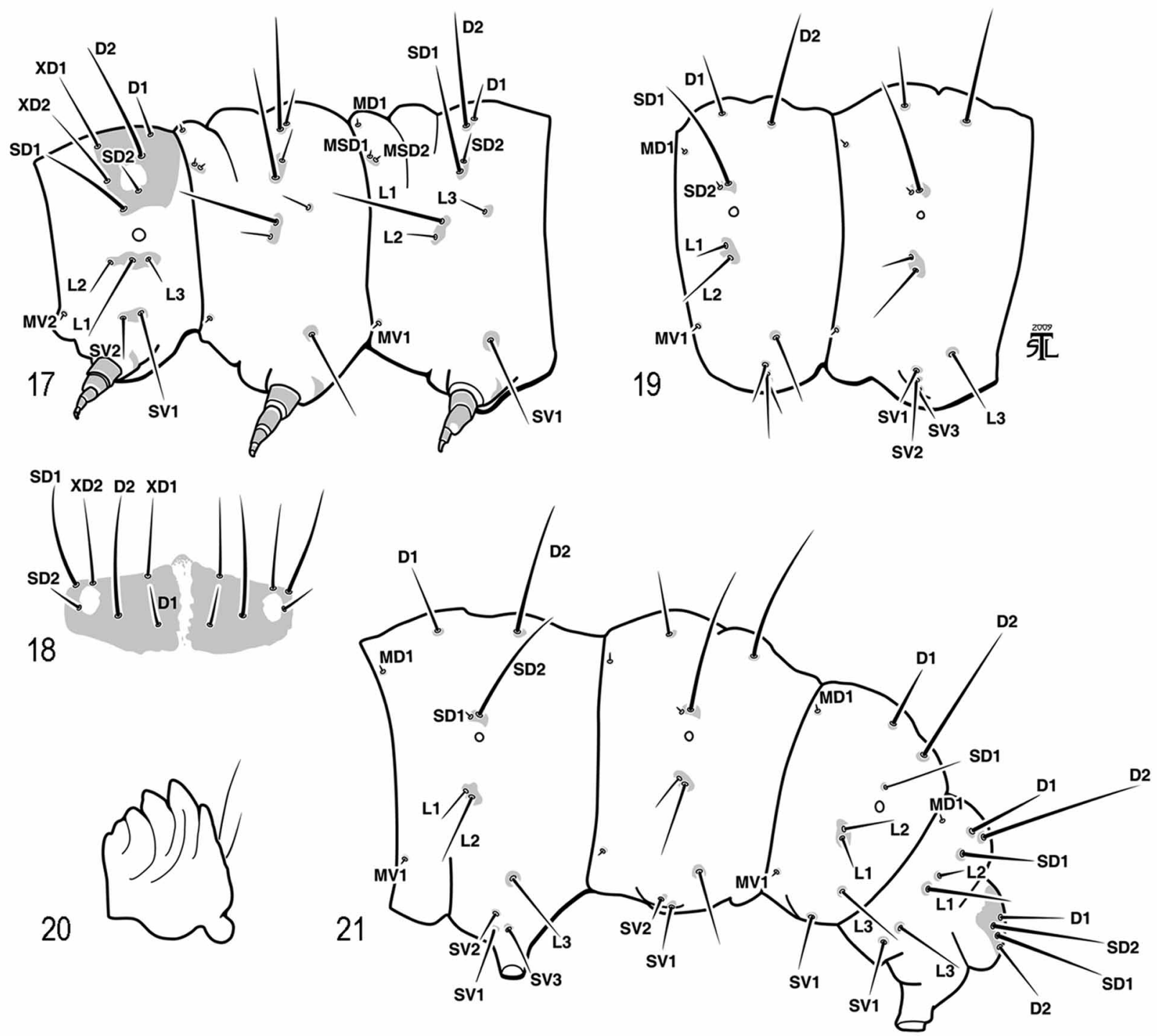

FIGURES 17-21. Chaetotaxal maps and right mandible of Blastobasis repartella. 17, thorax, lateral view; 18, thorax, dorsal view; 19, A1-A2, lateral view; 20, right mandible, inner view; 21, A6-A10, lateral view.

Distribution. Blastobasis repartella was known only from the type locality, Denver, Colorado for nearly 100 years until it was rediscovered recently from farm locations in Brookings, Hughes, and Marshall Counties, South Dakota (Fig. 24), and later from Champaign County, Illinois. A regional survey in the central United States (Prasifka et al. 2009), reported that B. repartella is now known to infest switchgrass in eight northern states including Illinois, Iowa, Michigan, Nebraska, North Dakota, Ohio, South Dakota, and Wisconsin but was not detected in Arkansas, Louisiana, Oklahoma, and Texas. Combined with the original collections by Dietz (1910), distribution in the U.S. appears to cover from an area Colorado east to Ohio and as far north as North Dakota.

Parasitoids. Two specimens of Bassus difficilis Muesebeck (Hymenoptera: Braconidae) were reared from pupae of B. repartella in South Dakota. 


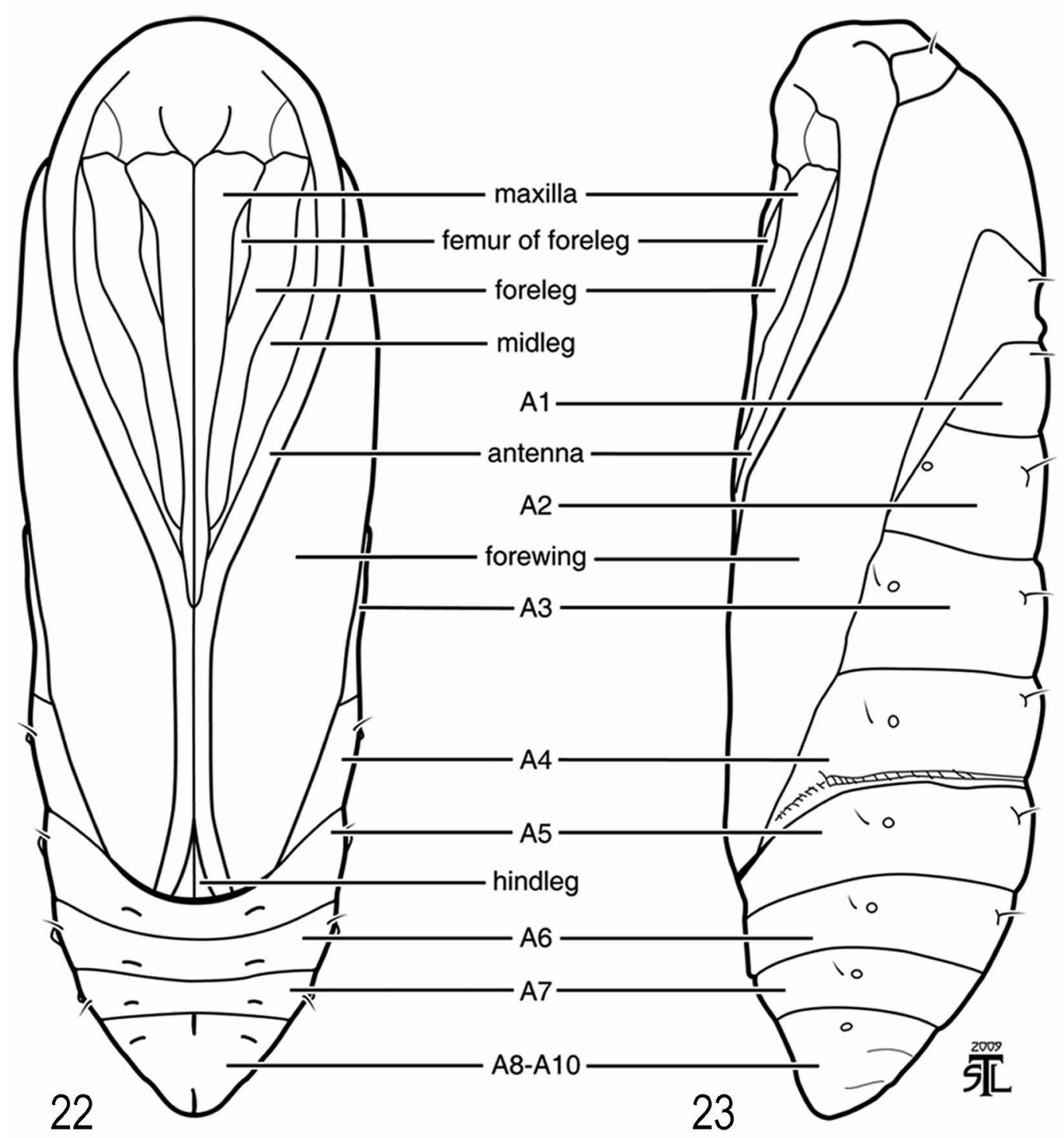

FIGURES 22-23. Pupa of Blastobasis repartella. 22, ventral view; 23, lateral view ("maxilla is proboscis).

Biology. Larval feeding on switchgrass by $B$. repartella is visible as partially emerged leaves on a tiller that desiccates and eventually dies (Fig. 25). These are symptoms similar to those produced by other stem boring insects in grass crops (e.g., Davis \& Pedigo 1991). The larva of B. repartella appears to be a monophagous stem-borer in the proaxis, basal nodes, and internodes of Panicum virgatum (Fig. 26). The proaxis of switchgrass is a region of several compressed nodes and internodes at the proximal end of a tiller. Adventitious roots and axillary meristems that give rise to the subsequent generation of extravaginal and intravaginal tillers are produced in this region (Brejda et al. 1989). The proaxis is metabolically active and is presumably a rich source of nutrients for herbivores.

Early instars of $B$. repartella may be found by mid-autumn. Presumably, larvae are inactive during the coldest months but were found to be active in South Dakota when plants were brought into the greenhouse in early spring and forced into early growth. In the field, late-instars are commonly found in late May actively feeding.

Pupae are found primarily during mid to late June within the plant stem (Fig. 27). However, no viable pupae have been found in the field in early July in Illinois or by the third week of July in South Dakota.

Flight period. Adults of $B$. repartella are nocturnal with a peak of activity during the early pre-sunrise hours. In eastern South Dakota, adult activity occurs from mid-July to mid-August, however, individuals are occasionally collected at evening lights during late August. Seasonal peak adult activity related to 
reproductive behavior was measured by the frequency of arriving males (40-50 males per night and occasionally exceeding 75 males per night) at cages containing calling females (Figs. 28-29). The flight period at Savoy, Illinois appears to be 2-3 weeks earlier than in South Dakota.

There is no evidence to suggest the occurrence of a second generation or overlapping cohorts in either South Dakota or Illinois populations. This is consistent with the single per year growth of switchgrass and appears to correlate with geographic variations in growing season differences of switchgrass (Quinn 1969) indicating that these populations lack sufficient phenological opportunity to support multiple generations of $B$. repartella.

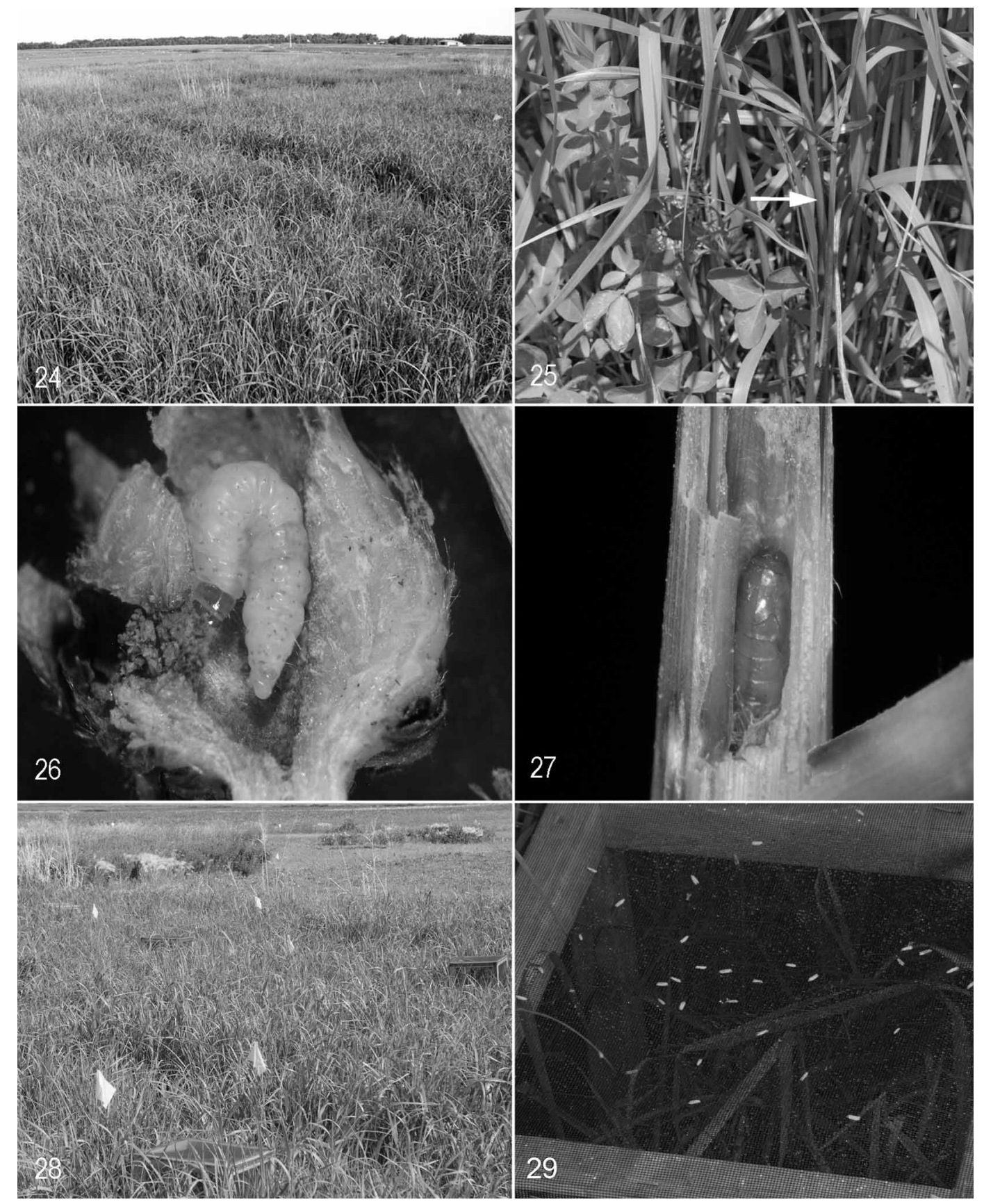

FIGURES 24-29. Habitat, larva, damage, pupa, and male adults of Blastobasis repartella. 24, switchgrass plots on the Aurora Farm in South Dakota; 25, arrow pointing to dead tiller of switchgrass plant caused by stem-boring larva of $B$. repartella; 26, larva in proaxis of switchgrass plant; 27, pupa within stem of switchgrass; 28 , cages placed in switchgrass plots in South Dakota; 29, males of Blastobasis repartella congregated on screen of field cages containing calling females. 
Oviposition. Eggs are deposited in a concealed area between the stem and desiccated sheath found at the base of the tillers (Prasifka et al. 2009).

Niche competitors. The only known potential niche competitor of B. repartella is Aethes spartinana (Barnes and McDunnough) (Lepidoptera: Tortricidae), which was reared from larvae also collected from stems of switchgrass in South Dakota. Previously, prairie cordgrass (Spartina pectinata Bosc ex Link.) was the only recorded host of A. spartinana.

\section{Discussion}

Switchgrass is a North American native warm-season grass that is widespread in a variety of grassland vegetational types and communities, including ruderal areas, old fields, scattered natural and anthropogenic mesic sites, and horticultural plantings. Few insects are recorded as herbivores of switchgrass, and they appear, as a group, restricted to a few species of Lepidoptera (Metzler et al. 2005) and acridid grasshoppers. Switchgrass is presently one of a number of native species of plants being studied as potential crops for biofuels feedstock (Parish \& Fike 2005). Yet, despite this agronomic attention, serious consideration of its herbivores has been ignored until recently. Reviews on the plant have noted the palatability of the plant to grasshoppers (Vogel 2004), while Parrish and Fike (2005) added only an incidental occurrence of the sugar cane aphid, Sipha flava (Forbes 1884) (Aphididae) and an undetermined thrips on plants grown in Germany, while Sanderson et al. (2006) curiously provided no information on associated insects. However, more recently Gonzalez-Hernandez et al. (2009) emphasized the need for a proactive approach to the biology of potential disease and insect pests of perennial grasses that are candidates for biomass feedstock production.

The rediscovery of $B$. repartella is itself most interesting, particularly with regard to the now documented wide distribution of the species and its ecological associations. Blastobasis repartella shares with B. graminea the larval stem-boring habit in grasses and similar immature morphology and adaptations. Curiously, it appears that $B$. repartella is not uncommon, but possibly its apparent host restriction to switchgrass, its cryptic and nocturnal behavior together with its small size, combined with the lack of knowledge of blastobasines in the U.S. has enabled it to being overlooked for so long.

This species was discovered in South Dakota and later in Illinois causing damage to plant tillers. In South Dakota, Boe observed (pers. obs. 2004) a wide variation among individual plants of switchgrass for frequency of tillers infested by $B$. repartella. Although, stands were not adequately sampled to provide a point estimate of the frequency of tiller infestation, these observations suggest that individual plants with significant infestation were infrequent. Direct estimates of damage to switchgrass were provided by Prasifka et al. (2009). They had determined that damage to switchgrass was no higher than 10 per cent based on samples of 500 or 1000 randomly selected tillers from multiple locations throughout central United States, including the Great Plains. Undoubtedly, more work is needed to determine the impact of B. repartella in prairie ecosystems as well as switchgrass monocultures managed for biomass production.

In a curious but not unpredictable manner, the discovery of $B$. repartella is an example of our incomplete knowledge of the prairie biological diversity and the impact of a species interacting with human agricultural practices. Anticipated land use changes in agriculture are underway to accommodate a growing cellulosic market (USDOE 2006). The association of $B$. repartella and commodified switchgrass illustrates that biological components of system that were once in decline may change direction. Such changes underscore the need to understand species such as B. repartella, and demand closer attention to the life histories of native species.

\section{Acknowledgments}

We thank Scott Whittaker, Lab Manager, Scanning Electron Microscopy Laboratory, Smithsonian Institution, Washington, DC, for the suggestions on larval fixation prior to SEM analysis, and for the scheduling of scope 
time; Sara L. Taliaferro, Lawrence, Kansas, for the fine computer generated illustrations of the larva and pupa and production of plates; and Mike Sharkey, University of Kentucky, for the identification of Bassus difficilis. Funding for A. Boe, on forage breeding research is supported by the South Dakota Agricultural Experiment Station; the U.S. Department of Energy through the Great Plains Institute for Sustainable Development in Minneapolis, the Department of Energy's biomass program through the Oak Ridge National Laboratory, and the North Central Sun Grant Center at South Dakota State University; P. Johnson, on insect herbivores of switchgrass by the South Dakota's Agricultural Experiment Station and the Burruss McDaniel Insect Collection Endowment (South Dakota State University Foundation), and for B. Bradshaw through the Energy Biosciences Institute, University of Illinois, Urbana, Illinois.

\section{Literature}

Adamski, D. (1999) Blastobasis graminea, new species (Lepidoptera: Gelechioidea: Coleophoridae: Blastobasinae), a stem borer of sugar cane in Colombia and Venezuela. Proceedings of the Entomological Society of Washington, 101, 164-174.

Adamski, D. \& Brown, R.L. (1987) Morphology and Systematics of North American Blastobasidae (Lepidoptera: Gelechioidea). Mississippi Agricultural and Forestry Experiment Station Technical Bulletin 165. Mississippi Entomological Museum Publication No. 1, 70 pp.

Adamski, D., Copeland, R.S., Miller, S.E., Hebert, P.D.N., Darrow, K. \& Luke, Q. (2010) A review of African Blastobasinae (Lepidoptera: Gelechioidea: Coleophoridae), with new taxa reared from native fruits in Kenya. Smithsonian Institution Scholarly Press, Number 630, vi + 68 pp.

Adamski, D. \& Hodges, R.W. (1996) An annotated list of North American Blastobasinae (Lepidoptera: Gelechioidea: Coleophoridae). Proceedings of the Entomological Society of Washington, 98, 708-740.

Brejda, J.J., Moser, L.E. \& Walker, S.S. (1989) Rhizome and tiller development of three Nebraska Sanhills warm-season grasses, pp. 211-215. In, T.B. Bragg and J. Stubbendieck, eds. Prairie Pioneers: Ecology, History, and Culture. Proceedings of the Eleventh North American Prairie Conference, Held 7-11 August 1988, Lincoln, Nebraska. University of Nebraska Printing, Lincoln, Nebraska.

Chipperfield, H.E. (1978) Blastobasis decolorella Wollaston (Lep., Blastobasidae). Entomologist's Record and Journal of Variation, 90, 19.

Clarke, J.F.G. (1941) The preparation of slides of the genitalia of Lepidoptera. Bulletin of the Brooklyn Entomological Society, 36, 149-161.

Dickson, R.J. (2002) Blastobasidae. Pp. 196-203. In, Emmet, A.M. and Langmaid, J.R. (eds.), The Moths and Butterflies of Great Britain and Ireland. Vol. 4(1). 326 pp. Colchester.

Davis, P.M. \& Pedigo, L.P. (1991) Injury profiles and yield responses of seedling corn attacked by stalk borer (Lepidoptera: Noctuidae). Journal of Economic Entomology, 84, 294-299.

Dietz, W.G. (1910) Revision of the Blastobasidae of North America. Transactions of the Entomological Society of America, 36, 1-72.

Gonzalez-Hernandez, J., Sarath, G., Stein, J.M., Owens, V., Gedye, K. \& Boe, A. (2009) A multiple species approach to biomass production from native herbaceous perennial feedstocks. In Vitro Cellular and Developmental BiologyPlant, 45, 267-281.

Jakob, K., Zhou, F. \& Paterson, A. (2009) Genetic improvement of C4 grasses as cellulosic biofuel feedstocks. In Vitro Cellular \& Developmental Biology-Plant, 45, 291-305.

Kornerup, A. \& Wanscher, J.H. (1978) Methuen Handbook of Colour. $2^{\text {nd }}$ ed., Methuen and Co., Ltd., London. 243 pp.

Metzler, E.H., Shuey, J.A., Ferge, L.A., Henderson, R.A. \& Goldstein, P.Z. (2005) Contributions to the Understanding of Tallgrass Prairie-Dependant Butterflies and Moths (Lepidoptera) and their Biogeography in the United States. Bulletin of the Ohio Biological Survey, 15, 1-143.

Mosher, E. (1916) A classification of the Lepidoptera based on characters of the pupa. Bulletin of the Illinois State Laboratory of Natural History, 12, $159 \mathrm{pp}$.

O'Keeffe, D. (1991) A note on the life history of Blastobasis decolorella (Woll.). Entomologist's Record and Journal of Variation, 103, 282.

Parrish, D.J. \& Fike, J.H. (2005) The biology and agronomy of switchgrass for biofuels. Critical Reviews in Plant Sciences, 24, 423-459.

Prasifka, J.R., Bradshaw, J.D., Boe, A.A., Lee, D.K., Adamski, D. \& Gray, M.E. (2009) Symptoms, distribution and abundance of the stem-boring caterpillar, Blastobasis repartella (Dietz), in switchgrass. BioEnergy Research, DOI:10.1007/s12155-009-9064-8.

Quinn, J.A. (1969) Variability among High Plains populations of Panicum virgatum. Bulletin of the Torrey Botanical 
Club, 96, 20-41.

Samson, F. \& Knopf, F. (1994) Prairie conservation on North America. Bioscience, 44, 418-421.

Sanderson, M.A., Adler, P.R., Boateng, A.A., Casler, M.D. \& Sarath, G. (2006) Switchgrass as a biofuels feedstock in the USA. Canadian Journal of Plant Science, 86, 1315-1325.

Schmer, M.R., Vogel, K.P., Mitchell, R.B. \& Perrin, R.K. (2008) Net energy of cellulosic ethanol from switchgrass. Proceedings of the National Academy of Sciences, 105, 464-469.

Stehr, F.W. (1987) Immature Insects. Stehr, F.W. Editor. Kendall/Hunt Pub. Co., Dubuque, Iowa. xiv + 754 pp.

Tilman, D., Hill, J. \& Lehman, C. (2006) Carbon-negative biofuels from low-input high diversity grassland biomass. Science, 314, 1598-1600.

[USDOE] U.S. Department of Energy. (2006) Feedstocks for biofuels. In, Breaking the Biological Barriers to Cellulosic Ethanol: A Joint Research Agenda, DOE/SC-0095. U.S. Department of Energy, Washington, DC. (http:// genomiscstgl.energy.gov/biofuels/2005workshop/2005low_feedstocks.pfd).

Vogel, K.P. (2004) Switchgrass, pp. 561-588. In, L.E. Moser, B.L. Burson, and L.E. Sollenberger, eds., Warm-Season (C4) Grasses. American Society of Agronomy, Corp Science Society of America, and Soil Science Society of America, Madison, Wisconsin. 1194 p.

Vogel, K.P. \& Mitchell,R.B. (2008) Heterosis in switchgrass: biomass yield in swards. Crop Science, 48, 2159. 